\title{
Peranan koperasi Syariah dalam meminimalisir ketergantungan masyarakat berhubungan dengan rentenir
}

\author{
Iskandar \\ STKIP PGRI Sumenep, Indonesia \\ iskandarjohar@yahoo.co.id
}

\begin{abstract}
The purpose of this study was to determine the role of Mitra Surya Bahari Islamic Women's Cooperatives in minimizing the dependency people of Aeng Dake village. This type of research is classified into qualitative research using interviews, observation, and documentation to obtain data, then the data is analyzed to obtain conclusions and verification. Based on the findings, the existence of Islamic women's cooperatives in minimizing people's dependence on capital loans from Ribawi financial institutions or from loan sharks is very large. Especially in helping community financing as productive business capital and in meeting household needs. The role of Islamic cooperative is increasingly felt when it becomes a facilitator and acomudator in training and providing counseling to the community to be productive both in agriculture, animal husbandry, and the skill area, both culinary and craft.
\end{abstract}

Keywords: Islamic Cooperative, Loan Shark, Ribawi Financial Institution

\section{PENDAHULUAN}

Peranan lembaga keuangan sangatlah penting dalam membangun perekonomian suatu masyarakat. Kehadirannya seolah menjadi jantung yang memompa denyut nadi perekonomian masyarakat, semakin besar peranannya kepada masyarakat maka semakin lancar perputaran roda perekonomian mereka. Bahkan menurut Muhammad sistem mekanisme keuangan suatu negara telah menjadi instrumen penting dalam memperlancar jalannya pembangunan suatu bangsa. (Muhammad, 2002: 15) Oleh karena pentingnya keberadaan lembaga keuangan, maka negara mengaturnya dalam Undang-undang No. 14 Tahun 1967 tentang perbankan.

Menurut UU No. 14 Tahun 1967 pasal 1 lembaga keuangan berarti badan usaha yang kegiatannya menghimpun dana dari masyarakat dan kemudian menyalurkannya kembali kepada masyarakat. Tidak jauh berbeda dari pengertian di lembaga keuangan menurut UU No. 14 Tahun 1967 lembaga keuangan menurut SK Menkeu RI No. 92 Th. 1990 adalah semua badan usaha yang bergerak di bidang keuangan dimana kegiatannya menghimpun dana dan menyalurkannya kepada masyarakat terutama untuk pelayanan investasi pembangaunan. 
Secara umum lembaga keuangan dapat diklasifikasikan menjadi lembaga keuangan bank maupun non bank. Lembaga keuangan bank menurut Undang-undang No. 10 Tahun 1998 adalah badan usaha yang menghimpun dana dari masyarakat dalam bentuk simpanan dan menyalurkannya kepada masyarakat dalam bentuk kredit dan atau bentuk-bentuk lainnya dalam rangka meningkatkan taraf hidup rakyat banyak. Sedangkan lembaga keuangan non-bank atau biasa disebut Lembaga Keuangan Bukan Bank (LKBB) berdasarkan surat keputusan menteri keuangan RI No. KEP-38/MK/IV/1927 adalah semua lembaga yang melakukan kegiatan di bidang keuangan yang secara langsung atau tidak langsung menghimpun dana terutama dengan jalan mengeluarkan kertas berharga dan menyalurkannya kepada masyarakat, terutama guna membiayai investasi perusahaanperusahaan.

Berdasarkan pengertian di atas dapat dipahami bahwa peranan dan fungsi lembaga keuangan seperti bank dalam menggerakkan roda perekonomian di tengah masyarakat menjadi sangat vital. Keberadaan perbankan seolah menjadi mitra masyarakat dalam aktifitas berekonomi mereka. Namun meski demikian, aktifitas ekonomi masyarakat tidak sepenuhnya bergantung kepada lembaga keuangan seperti perbankan. Praktik di lapangan menunjukkan gejala perilaku ekonomi yang menarik. Masyarakat tidak hanya mendapatkan pinjaman uang dari lembaga keuangan seperti bank ketika mengalami defisit anggaran, tetapi juga dari lembaga keuangan non bank dan perorangan yang umum diistilahkan dengan rentenir yang menjadi tumpuan akses mereka dalam melakukan transaksi pinjaman pada saat mereka mengalami defisit anggaran.

Meski pada satu sisi datang dengan memberikan kemudahan akses untuk memenuhi kebutuhan modal warga, namun pada sisi yang lain kehadiran mereka mendatangkan masalah baru atas pinjaman (kredit) yang mereka berikan, mulai dari tingkat bunga, periode cicilan dan sebagainya. Dalam contoh bunga pinjaman, praktik yang mereka lakukan biasanya menetapkan simple interest (bunga sederhana), yaitu mengkalikan uang pokok pinjaman dengan prosentase tertentu. Dan penetapan bunga inilah yang kemudian menjadi permasalahan pokok para nasabah. Bunga yang dibayarkan nasabah yang bersifat fixed (tetap) secara otomatis menjadi fixed cost (biaya tetap) bagi bisnis mereka. Dan secara konstan akan menaikkan tingkat harga komoditas atau barang yang mereka perdagangkan pula, seta mempengaruhi tingkat belanja konsumen yang mereka miliki. (ElDiwany, Tarek, 2003: 77)

Penetapan bunga atas kredit menjadi beban yang sangat memberatkan nasabah terlebih pada saat skim kredit yang diambil hanya untuk memenuhi kebutuhan keluarga saja. Pinjaman atau kredit yang diperuntukkan bagi keperluan yang tidak produktif menjadikan mereka terlilit hutang yang semakin besar karena jumlah pengembalian pokok pinjaman ditambahkan dengan bunga, terlebih biasanya penetapan bungan oleh lembaga keuangan non bank tergolong tinggi dengan iming-iming kemudahan akses pinjaman yang mereka berikan bagi nasabah. Lembaga keuangan atau perorangan tidak sepenuhnya tulus membantu nasabah dalam memberikan pinjaman untuk mengatasi kesulitan ekonomi mereka. Orientasi keuntungan secara materi bagi mereka lebih diprioitaskan dibandingkan motivasi untuk menolong kesulitan yang dialami nasabah dengan asas kekeluargaan. Bahkan pada suatu kondisi tertentu seperti menghadapi keterlambatan angsuran kredit atau kredit bemasalah, tanpa sungkan petugas mereka melalukan perampasan atau penyitaan 


\section{Vol. 2 No. 1 June 2020}

agunan tanpa mempehatikan nilai-nilai kekeluargaan bahkan kemanusiaan.

Menjamurnya praktik bisnis dengan penerapan bunga sebagai orientasi meraup keuntungan oleh lembaga keuangan bank maupun non bank dewasa ini memupuk tumbuhkembangnya nilai-nilai kapitalisme dengan menjadikan mereka (para pemilik modal) semakin kaya dengan kekayaan yang mereka dapatkan dari memerah keringat para nasabah yang notabeni masyarakat miskin yang kekurangan modal. Praktik bisnis keungan dengan penerapan bunga merupakan suatu kondisi yang jauh dari cerminan membangun masyarakat yang adil dan makmur serta sejahtera sebagaimana menjadi salah satu tujuan negara Indonesia yang tertuang dalam pembukaan UUD 1945, serta menciderai nilai-nilai pancasiala, yakni nilai kemanusiaan, keadilan dan peradaban, seperti termaktub pada sila ke-2 dan ke-5.

Islam menggolongkan bunga sebagai riba yang jauh dai nila-nilai syar'i dan sangat merugikan masyarakat (Islahi, 1998:128). Bunga itu sendiri dapat dipahami sebagai tanggungan pada pinjaman uang yang biasanya dinyatakan dengan persentase dari uang yang dipinjamkan. (Muhammad, 2005:40) Praktik riba dilarang keras di dalam Islam sebagaimana larangannya termaktub dalam al-Quran untuk tidak mendzalimi satu sama lain. $^{2}$ Riba itu sendiri berarti tambahan uang atas modal yang diperoleh dengan cara yang tidak dibenarkan secara syar'ie baik sedikit maupun banyak. Oleh ulama fiqh riba didefinisikan sebagai kelebihan harta dalam suatu muamalah dengan tidak ada imbalan/gantinya. Atinya tambahan uang atas modal yang timbula akibat tansaksi hutangpiutang yang harus dibeikan kepada pemilik modal atau pembei pinjaman (Muhammad, 2005: 41).

Islam datang sebagai rules of life (Panduan hidup) dalam segala aspek kehidupan. Di dalam praktik bisnis, aturan dalam Islam tidak hanya memberikan keuntungan sepihak negatif sum game melainkan positve-sume game (keuntungan semua pihak yang bertransaksi), (Bakar, 2008: 22). Di dalam Islam, etika mendominasi ekoomi yang seluruh tatalaksannaya berpolakan orma etis dan bukan sebaliknya (Nazir, 2008:30). Islam dirancang sebagai rahmat untuk seluruh ummat untuk menjadikan hidup lebih sejahtera. Islam bertujuan untuk membentuk masyarakat dengan tatanan sosial yang setiap individu diikat oleh persaudaraan dan kasih sayang bagai keluarga yang bersifat universal tidak terbatas oleh geografis. Setiap individu dalam islam memiliki derajat yang sama di hadapan Allah hanya ketakwaanlah yang yang membedakan satu sama lainnya. Dalam konsep ekonomi, Islam melarang praktik eksploitasi satu sama lain, dan setiap orang mendapatkan haknya tanpa mengambil hak dan bagian orang lain. (Antonio,2009:13-15)

Inilah salah satu alasan munculnya lembaga keuangan syariah yang hendak menyajikan solusi yaitu memberikan modal usaha tanpa beban bunga. Lembaga Keuangan Islam seolah menjadi anti tesis terhadap praktik transaksi lembaga keuangan ribawi (lembaga keuangan yang menerapkan bunga). Lembaga Keuangan Islam menjadi sangat penting untuk mengeliminisir praktik rentenir di tengah masyarakat. Dari sekian banyak lembaga keuangan syariah, koperasi-lah yang paling tepat karena banyak bersinggungan dengan para nasabah yang aktif berhubungan dengan rentenir seperti pedagang pasar maupun tradisional.

\footnotetext{
2 Larangan praktik riba QS. An-Nisa' ayat 160-161
} 
Membangun koperasi dengan berlandaskan prinsip syar'i merupakan salah satu cara untuk meminimalisir praktik ketidakadilan dalam ekonomi serta dalam wujud membangun perekonomian masyarakat yang sejahtera. Karena tujuan pendirian koperasi menurut undang-undang perkoperasian adalah untuk memajukan kesejahteraan anggota pada khususnya dan masyarakat pada umumnya serta turutserta membangun tatanan perekonomian nasional dalam rangka mewujudkan masyarakat yang maju, adil, dan makmur berdasarkan Pancasila dan Undang-Undang Dasar 1945. Menurut Undangundang No. 25 tahun 1992, Bab I, Pasal 1, ayat 1 tentang perkoperasian menyatakan bahwa koperasi adalah badan us aha yang beranggotakan orang-orang atau badan hukum koperasi dengan melandaskan kegiatannya berdasarkan prinsip koperasi sekaligus gerakan ekonomi rakyat yang berdasar atas asas kekeluargaan.

\section{KAJIAN LITERATUR}

\section{Pengertian, Tujuan dan Karakteristik Koperasi Syariah}

Sebelum membahas lebih jauh mengenai koperasi syariah telebih dahulu penulis paparkan pengertia koperasi. Secara umum koperasi atau dalam bahasa Arab disebut syirkah ta'awuniyah dapat dipahami sebagai badan usaha di bidang perekoimian yang memiliki keanggotaan sukarela atas dasar persamaan hak, kerjasma, dan tujuan untuk memiliki kebutuhan para anggota serta masyarakat umum. (Nazir, 2008: 369). Menurut Undang-undang No. 25 tahun 1992 koperasi meupakan badan usaha yang beranggotakan orang atau badan hukum koperasi dengan melandaskan kegiatannya berdasarkan prinsip koperasi sekaligus sebagai gerakan ekonomi rakyat yang berdasar atas asas kekelurgaan (Ritongga, 2003: 200).

Secara definitif koperasi syariah memiliki pengertian yang tidak jauh berbeda dengan koperasi konvensional namun tujuan dan kegiatan usahanya berdasarkan pada syariah Islam yaitu al-Quran dan Assunnah. Kegiatan usaha di koperasi syariah biasanya bergerak dibidang pembiayaan, investasi, dan simpanan akan tetapi polanya berbeda dengan koperasi konvensional yakni sesuai dengan prinsip bagi hasil (Syariah). atau dikenal juga dengan istilah koperasi jasa keuangan syariah (KJKS). Sebagai contoh, di koperasi umum produk jual beli diganti namanya dengan istilah murabahah, produk simpan pinjam dalam koperasi umum berganti nama dengan mudharabah. Pinjaman berubah menjadi pembiayaan yang akad dan prinsipnya tidak sama dengan sistem konvesional ke sistem syari'ah yang sesuai dengan aturan Islam.

Secara umum tujuan dari koperasi syariahpun memiliki kemiripan dengan tujuan yang terdapat pada koperasi konvensional. Tujuan koperasi syariah untuk menyejahterakan ekonomi anggotanya sesuai norma dan moral Islam, terciptanya praktik ekonomi yang berkeadilan dan menciptakan ukhuwah (persaudaraan) sesama anggota, pembagian keuntungan dan kekayaan yang proporsional sesama anggota, Kebebasan pribadi dalam kemaslahatan secara umum yang didasarkan pada pengertian bahwa manusia diciptakan hanya untuk tunduk kepada Allah, Meningkatkan kesejahteraan anggota pada khususnya dan masyarakat pada umumnya serta turut membangun tatanan perekonomian yang berkeadilan sesuai dengan prinsip-prinsip Islam. Nur S, dkk, 2010: 17)

Koperasi syariah memiliki karakteristik sebagai berikut: (Janwari, 2000:108). 


\section{Vol. 2 No. 1 June 2020}

1. Mengakui hak milik anggota terhadap modal usaha

2. Tidak melakukan transaksi dengan menetapkan bunga (riba)

3. Berfungsinya institusi ziswaf

4. Mengakui mekanisme pasar yang ada

5. Mengakui motif mencari keuntungan

6. Mengakui kebebasan berusaha

7. Mengakui adanya hak bersama

\section{Landasan Koperasi Syariah}

Landasan koperasi syariah meliputi beberapa hal sebagaimana berikut: (Afrianti, 2010: 21)

a. Koperasi syariah berlandaskan syariah Islam yakni al-quran dan as-sunnah dengan prinsip ta'awun (saling tolong menolong) dan takaful (saling menguatkan)

b. Koperasi syariah berlandaskan Pancasila dan Undang-Undang Dasar 1945.

c. Koperasi syariah berlandaskan peratuan Menteri Negara Koperasi dan Usaha Kecil dan Menengah Republik Indonesia Nomor: 35.2/PER/M.KUKM/X/2007 tentang Pedoman Standar Operasional Manajemen Koperasi Jasa Keuangan Syariah

d. Koperasi syariah berazaskan Ukhuwah (persaudaraan dan kekeluargaan).

\section{Perbedaan Prinsip Operasional Koperasi Syariah dan Koperasi Konvensional}

Pada praktikya koperasi konvensional berorientasi mencari keuntungan untuk kesejahteraan anggota, baik dengan cara tunai atau membungakan uang yang ada pada anggota. Para anggota yang meminjam biasanya dikenakan bunga tetap untuk semua skim pinjaman, baik untuk memenuhi kebutuhan keluarga sehari-hari ataupun sebagai modal usaha. Dimana hal ini berbeda dengan prinsip operasional yang terjadi di koperasi syariah. Karena di koperasi syariah setiap transaksi (tasharuf) didasarkan atas penggunaan yang efektif apakah untuk pembiayaan atau kebutuhan sehari-hari. Kedua hal tersebut diperlakukan secara berbeda. Untuk usaha produktif, paa anggota dapat melakukan pinjaman modal pembiayaan dengan prinsip bagi hasil (Musyarakah atau Mudharabah) prinsip jual beli (Murabahah) untuk kebutuhan akan barang yang pembayarannya bisa dikredit tanpa memberlakukan denda keterlambatan pembayaran. (Afrianti, 2010: 22)

\section{Fungsi Koperasi Syariah}

Secara umum fungsi koperasi syariah antara lain: (Afrianti, 2010: 22)

a. Sebagai Manajer Investasi

Manajer investasi yang dimaksud adalah koperasi syariah menjadi peratara pemilik modal dengan anggota calon penerima modal usaha, dengan hanya medapatkan fee baik dari pemilik modal sebagai jasa atas roses seleksi ataupun biaya administrasi yang dikeluarkan sebagai ganti dari biaya monitoring dan reporting. Atau bisa dari anggota berupa administrasi apabila biasanya akad yang digunaka adalah mudharabah muayyadah. 
b. Sebagai Investor (Shahibul Maal)

Dalam hal ini koperasi syariah mengelola secara professional dana anggota maupun pinjaman dari pihak lain tanpa persyaratan khusus dari pemilik dana yang kemudian oleh pihak koperasi biasaya dialokasikan ke sektor bisnis riil sesuai syar'i. Prinsip pengelolaan dana tesebut dikeal dengan istilah Mudharabah Mutlaqah.

c. Fungsi sosial

Dalam hal ini koperasi syariah memberikan pelayanan sosial baik kepada anggota yang membutuhkannya maupun kepada masyarakat dhu'afa. Kepada anggota yang membutuhkan pinjaman darurat dapat diberikan pinjaman kebajikan (Qard) dengan pengembalian pokok saja tanpa adanya beban bunga sebagaimana koperasi konvensioal. Sementara bagi anggota masyarakat dhuafa dapat diberikan pinjaman kebajikan dengan atau tanpa pengembalian pokok yang sumber dananya dari dana ZIS (Zakat, Infaq, Shodaqoh).

\section{Produk-Produk Koperasi Syariah}

Dalam operasional kesehariannya kegiatan koperasi syariah meliputi usaha simpan pinjam dengan akad dan bentuk produk sebagaimana berikut: (Nazir, 2008: 373)

a. Penghimpunan dana dengan menggunakan akad wadi'ah atau Qard, yakni titipan yang dilakukan oleh anggota kepada pihak koperasi dan pihak koperasi betanggungjawab terhadap pengembalian titipan tersebut. Atau menggunakan akad mudharabah yakni akad dimana anggota menyimpan dana ke pihak kopeasi dan mereka memperoleh bagi hasil usaha atas simpanan meeka tersebut.

Beberapa produk penghimpunan dana koperasi adalah:
1) Simpanan Pokok
2) Simpanan wajib
3) Simpanan sukarela
4) Simpanan amanah

b. Penyaluran dana dalam bentuk:

1) Tabaru'

Tabarru' adalah peranjian dalam transaksi yang tidak untuk mencai keuntungan komersil. (A. Karim, 2009: 65) Dalam hal ini pihak koperasi menyalurkan dana kepada anggota tanpa mengharap kentungan komersil melainkan semata-mata menolong anggota.

2) Qard

Sesuai artinya yakni pinjaman, akad qard dalam koperasi selain digunakan dalam penghimpunan dana, juga digunakan dalam menyalurkan pembiayaan. Dalam hal ini pihak koperasi membeikan pinjaman cuma-cuma kepada pihak anggota yang membutuhkannya. Terkadang pihak koperasi dalam menerima simpanan dengan akad qard memberikan kelebihan kepada pemilik dana sebagai bentuk hasanah (kebaikan), sehingga yang demikian disebut qardul hasan. (Nazir, dkk, 2008: 540)

3) Jual beli :

- Bai biTsaman Ajil

Bai bi-tsaman ajil adalah jual beli dengan pembayaran ditangguhkan, 
bedasakan kesepakatan harga biasanya harga asal ditambahkan margin oleh pihak penjual karena adanya penangguhan waktu pembayaran. Dalam hal ini. praktik di kopeasi, pihak koperasi yang memberikan pembiayaan kepada nasabah atau anggotadalam angka memenuhi kebutuhan barang dengan sistem pembayaran angsuran/cilcilan, tanpa adanya denda keterlambatan pembayaran. (Nazir, dkk, 2008: 57)

\section{- Murabaha}

Murabaha adalah akad jual beli atas barang tertentu yang bersifat amanah. Biasanya dalam transaksi dengan akad ini pihak koperasi membeikan pembiayaan untuk nasabah dengan membelikan barang sesuai dengan spesifikasi pesanan nasabah dengan kesepakatan harga dan keuntungan yang diketahui oleh nasabah. (Nazir, dkk, 2008: 456).

\section{- Bai Salam}

Sedangkan akad salam adalah akad atau penjualan/pembuatan sesuatu yang disepakati dengan kriteria tertentu dalam waktu yang ditangguhkan penyelsesaiannya sedangkan pembayarannya disegerakan. (Nazir, dkk, 2008: 583). Dalam transaksi pembiayaan dengan akad ini biasanya pihak koperasi menyediakan pembiayaan dengan membayarkan secara tunai harga barang sesuai pesanan nasabah ke pihak produsen kemudian nasabah membayar ke piak koperasi setelah menerima barang.

4) Bagi Hasil

- Musyarakah

Sesuai dengan pengetian akad di atas secara syara' adalah transaksi antara dua orang atau lebih yang keduanya bersepakat untuk melakukan kerjasama usaha dengan tuuan memperoleh keuntungan melalui syarat dan rukun tetentu. (Nazir, dkk, 2008: 46). Dalam hal ini pihak koperasi dan nasabah sama mengeluarkan modal untuk bekerjasama dalam suatu usaha untuk mempeoleh keuntungan. Dan apabila tejadi kerugian maka kerugian tersebut ditanggung secara bersama-sama oleh pihak koperasi dan nasabah.

- Mudharabah

Mudharabah adalah akad kemitraan antara pemilik modal (shahibul maal) dan pengelola atau pengusaha dengan pembagian keuntungan usaha anatara kedua pihak sesuai kesepakatan. (Nazir, dkk, 2008: 448). Dalam transaksi pembiayaan ini piak koperasi bertindak sebagai shoibul maal sedangkan nasaba atau anggota sebagai mudharibnya.

5) Jasa Lainnya

\section{- Ijarah}

Ijarah adalah akad untuk mengambil manfaat dengan jalan penggantian. Atau dalam arti lain pemilikan manfaat dai sesuatu yang halal dalam jangka waktu tertentu dan dengan imbalan ganti rugi. Atau secara sederhana adalah penjualan manfaat. (Nazir, dkk, 2008: 278). Dalam akad ini pihak koperasi menyediakan barang yang akan disewa kepada nasabah. 


\section{Pengertian Rentenir}

Di suatu daerah tertentu di Indonesia, misalnya Jawa, rentenir adalah profesi yang sangat populer sebagai orang yang menawarkan pinjaman jangka pendek tanpa jaminan tetapi memiliki tingkat bunga yang relatif tinggi (sekitar 20\% selama satu periode kredit), dan mereka juga berusaha untuk menjaga hubungan kredit dengan nasabah-nasabahnya melalui hubungan interpersonal maupun kultural. Sebagian besar rentenir beroperasi di pasar-pasar pedesaan, dan mereka juga sering mengunjungi orang dari pintu ke pintu. (punyaudin.blogspot.co.id/2008/08/bmt-versus-rentenir.html diakses pada tanggal 12 november 2016).

\section{METODE PENELITIAN}

Penelitian ini merupakan penelitian kualitatif, yaitu penelitian yang menghasilkan data deskriptif berupa kata-kata tertulis atau lisan dari individu atau kelompok serta perilaku yang dapat diamati (Moleong, 1998:3). Untuk mencapai tujuan penelitian, pada penelitian ini digunakan beberapa metode, antara lain metode observasi (pengamatan). Metode ini digunakan dengan tujuan untuk mengumpulkan data dengan cara mengamati masyarakat yang menjadi obyek. Teknik ini terdiri dari pengamatan (observasi) dan observasi partisipasi. Dan tekhnik obsevasi dalam penelitian ini menggunakan observasi parsipatori, dimana penliti ditunutut terjun mengamati langsung situasi dan kondisi objek di lapangan. (Bungin, 2008: 190-191). Selain itu, dalam penelitian ini digunakan juga metode wawancara mendalam (indepth interview), dengan menggunakan pedoman wawancara terstruktur, ataupun tidak terstruktur sesuai kebutuhan dilapangan dengan tujuan memperoleh data yang dïnginkan. (Bungin, 2008: 67) Responden dalam penelitian ini adalah ketua Koperasi wanita syariah Mita Surya Bahari, beserta penguruspengurusnya dan dan beberapa anggota.

Untuk memperkaya data dan informasi, dalam penelitian ini juga digunakan metode dokumentasi (baca Arikunto, 2002: 135), yakni dokumentasi tertulis. Hal ini terutama yang berkaitan dengan objek penelitian atau dokumen-dokumen yang lain, RAT, Laporan Pembiayaan, dan lain sebagainya. Selanjutnya dilakukan analisis komprehensif atas datadata yang telah diperoleh. Karena sesungguhnya analisis data kualitatif adalah upaya yang dilakukan dengan jalan bekerja dengan data, mengorganisasi data, memilah-milahnya menjadi satuan yang dapat dikelola, mensistesiskannya, mencari dan menemukan pola, menemukan apa yang penting, dan apa yang dipelajari, dan memutuskan apa yang dapat diceritakan kepada orang lain. (Moleong, 2007:248)

\section{HASIL DAN PEMBAHASAN}

\section{Profil Koperasi Wanita Syariah Mitra Surya Bahari}

Koperasi Wanita Syariah Mitra Surya Bahari didirikan sejak tahun 2008, bertempat di desa Aeng Dake, kecamatan Bluto, kabupaten Sumenep dengan 6 orang pengurus, yang dipimpin oleh ibu Hamidah dan hingga saat ini telah memiliki anggota sebanyak 50 orang lebih. Pada praktik transaksinya koperasi ini mengalami peningkatan modal dan jumlah dari tahun ke-tahun. Tercatat sejak tahun 2008 Banyaknya anggota dengan modal sebesar Rp. 5.000.000 Kini banyak anggota mencapai 50 orang dan modal 


\section{Vol. 2 No. 1 June 2020}

mencapai Rp. 600.000.000.

Didirikannya Koperasi Wanita Syariah Mitra Surya Bahari sebagai perlawanan masyarakat khususnya desa Aeng Dake terhadap praktik rentenir yang terjadi di kalangan masyarakat. Banyaknya masyarakat terutama kaum hawa (ibu rumah tangga) yang berhubungan dengan rentenir sebagai kreditur dari beberapa lembaga keuangan berbasis riba, untuk meminjam uang guna memenuhi kebutuhan modal usaha atau kebutuhan rumah tangga mereka, bahkan yang lebih parah adalah sekedar memenuhi tren atau gaya hidup mereka. Kebutuhan akan kredit tersebut direspon positif oleh para rentenir dengan memberikan akses kemudahan pencairan pinjaman namun dengan konsekwensi membayar bunga yang cukup tinggi. Fenomen inilah yang kemudian mendorong masyarakat setempat terlilit hutang yang semakin hari semakin menumpuk. Berdirinya Koperasi Wanita Syariah Mitra Surya Bahari merupakan salah satu upaya masyarakat setempat melalui koordinasi dengan pemerintah desa setempat untuk meminimalisir hubungan masyarakat dengan para rentenir, melalui langkah-langkah strategis agar dapat menyelamatkan warga dari keterlilitan hutang sekaligus membantu memajukan ekonomi warga berdasarkan gotong royong dan kekeluargaan.

\section{Produk dan Jasa Keuangan Koperasi Wanita Syariah Mitra Surya Bahari}

Sebagaimana mengacu kepada panduan syariah dan disesuaikan dengan konsep operasional koperasi syariah yang ada, maka kegiatan operasional dan produk serta akad koperasi syariah mitra surya bahari dapat digambarkan dalam bagan berikut:

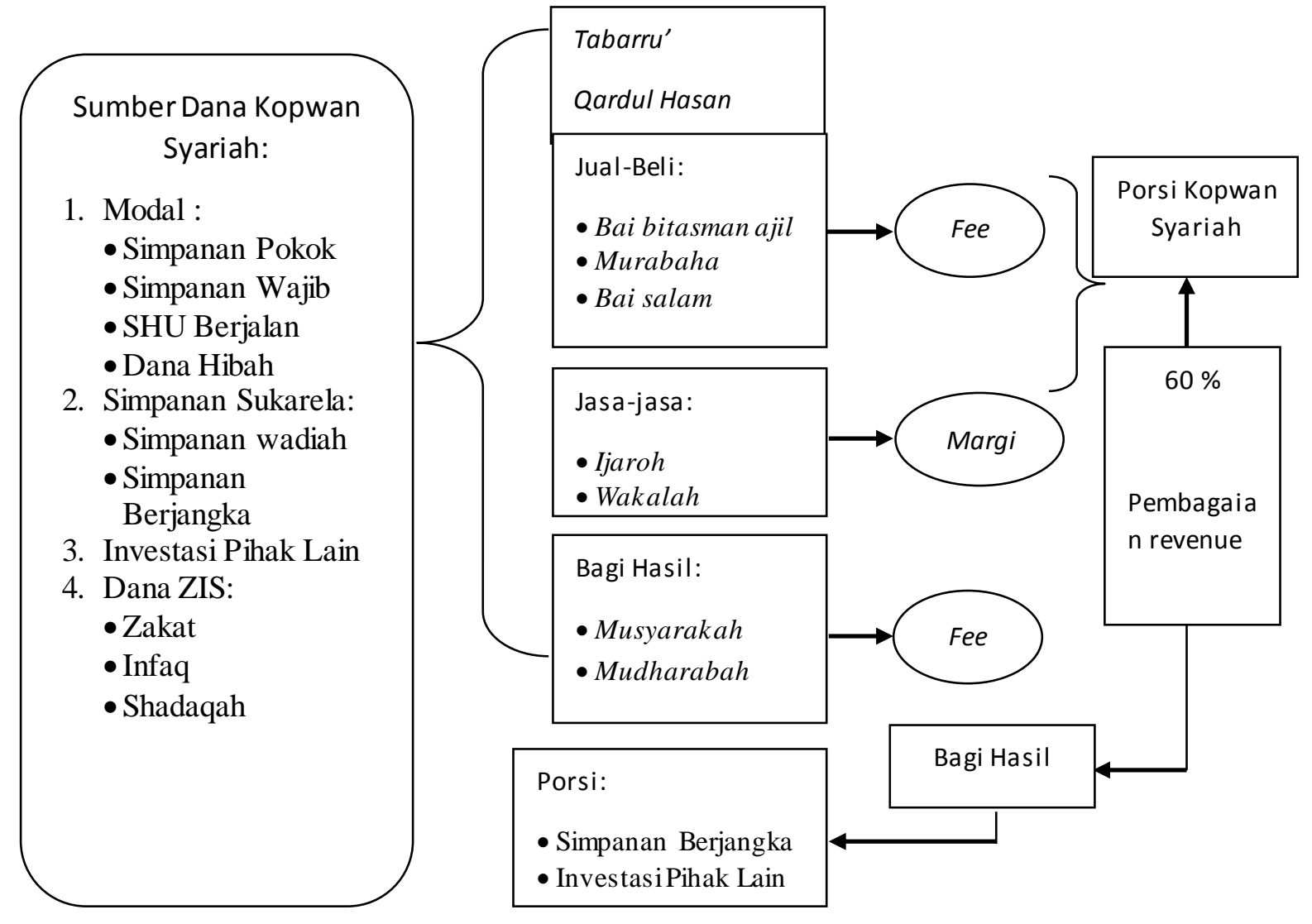




\section{Fenomena Praktik Hubungan Warga dengan Rentenir}

Praktik yang diterapkan rentenir atau tukang kedit di desa Aeng Dake diawali dengan bertemu masyarakat dengan menawarkan pinjaman tanpa agunan (jamianan pinjaman) untuk menarik minat nasabah, kecuali pinjaman dalam jumlah besar. Selanjutnya tanpa adanya persyaratan administrasi yang ketat, dan peminjam tidak perlu mengantar angsuran, karena akan dijemput oleh pemberi kredit. Biasanaya angsuran dibayar perhari atau perminggu, sesuai kesepakatan anatara pihak pemberi pinjaman dan yang yang meminjam. Bunga yang ditetapkan oleh pemberi pinjmana biasanya tergolong tinggi sekitar 20-30\% dari jumlah pinjaman untuk jangka waktu antara 30 - 60 hari. Misalnya seseorang meminjam uang sebesar Rp. 1000.000.- (satu juta rupiah), maka kepadanya dibebankan untuk mengembalikan hutang pokok dan bunganya secara cicilan sebesar Rp. 30.000.- 40.000. / hari selama kurun waktu 40 hari.

Pola hidup konsumtif yang menjangkiti masyarakat saat ini memberi dampak negatif bagi kehidupan mereka, tidak terkecuali masyarakat desa Aeng Dake. Bertemunya kebiasaan konsumtif masyarakat dengan akses pinjaman dana yang mudah seolah menjadi racun yang tampak seperti suplemen yang secara sadar atau tidak akan mendatangkan masalah besar bagi mereka. Adanya keluhan lilitan hutang yang menjerat beberapa masyarakat setempat seakan menjadi indikator bahwa masalah besar telah menerpa mereka, sekaligus menunjukkan bahwa banyak masyarakat yang berhubungan dengan rentenir.

\section{Peran Koperasi Wanita Syaiah Mitra Surya Bahari dalam Meminimalisir Hubungan Warga Desa dengan Para Rentenir}

Beberapa langkah strategis yang telah dilakukan oleh Koperasi Wanita Syariah Mitra Surya Bahari sebagai eksistensi lembaga keuangan non bank dan perannya dalam meminimalisir praktik rentenir di desa Aeng Dake kecamatan Bluto antara lain:

1. Rekrutmen Masyarakat sebagai Anggota Koperasi melalui kegiatan Arisan

Pertama berdiri Koperasi Wanita Syariah Mitra Surya Bahari, hanya terdiri dari 25 anggota yang didominasi oleh para kaum hawa di desa setempat, dan untuk memperluas keanggotaan dengan tujuan menjaring mereka agar tidak lagi berhubungan dengan rentenir, diadakanlah arisan ibu-ibu dengan serangkaian kegiatan di dalamnya mulai dari berdoa bersama, kajian hingga pelatihan. Perekrutan anggota baru lebih diprioritaskan kepada para mereka yang selalu bergantung kepada rentenir dalam menadikan alternatif untuk meminjam uang.

2. Memberikan Pembiayaan Kebutuhan Rumah Tangga

Keberadaan kopwan syariah sejatinya menjadi solusi terhadap masalah yang dihadapi warga desa terkait problem keuangan mereka. Oleh karenanya, orientasi dari upaya yang dilakukan semata untuk menolong dan membantu (tabarru') tidak semata orientasi bisnis dengan mencari keuntungan finansial, (Karim, 2009:66) yakni dengan tujuan meringankan poblema keuangan warga sehingga terhindar dari keterlilitan hutang karena besarnya beban bunga pinjaman yang mereka dapatkan dari rentenir. Maka setelah melakukan rekruitmen terhadap warga yang terindikasi masalah tersebut pengurus koperasi mengajak warga tersebut untuk bergabung menjadi anggota koperasi, mereka dibantu diberikan pinjaman modal tanpa bunga 


\section{Vol. 2 No. 1 June 2020}

untuk memenuhi kebutuhan rumah tangganya dengan mengguakan akad qard alhasan. Tentunya melalui persyaratan-persyaratan yang telah ditentukan. Diantara beberapa persyaratan tersebut:

1) Aktif mengikuti arisan dengan besaran iuran yang telah disepakati oleh anggota

2) Melakukan simpanan wajib tiap minggu bersamaan dengan waktu arisan.

3) Melakukan cicilan tiap minggu yang dibayar pada saat arisan. Dan apabila yang bersangkutan tidak sanggup membayar tiap minggu diberikan penangguhan waktu sampai yang bersangkutan sanggup melunasi pinjamannya.

4) Dan jika hingga pada akhirnya yang bersangkutan pun tidak sanggup melunasi dengan faktor yang tidak memungkinkan untuk melunasinya, misalnya karena kondisi ekonomi yang berkebutuhan atau yang bersangkutan meninggal dunia dan keluarganya tidak mampu melunasinya maka para anggota koperasi yang lain diminta kesediaanya untuk mengikhlaskannya.

5) Anggota diperkenankan meminjam dana untuk kebutuhan rumah tangganya dengan batas maksimal $70 \%$ dari total simpanan yang dia miliki di koperasi. Atau sampai dengan $100 \%$ jika yang bersangkutan belum mendapatkan arisan.

6) Anggota yang berada pada masa angsuran pelunasan pinjaman tidak diperkenankan untuk mengajukan pinjaman lagi.

3. Memberikan Pembiayaan Modal Usaha akad mudharabah atau musyarakah Selain memberikan pembiayaan kebutuhan rumah tangga bagi masyarakat agar tidak lagi bergantung kepada rentenir, Koperasi Wanita Syariah Mitra Surya Bahari juga membeikan pembiayaan modal usaha guna meningkatkan pendapatan rumah tangga warga desa. Pembiayaan modal usaha diberikan menggunakan akad mudharabah (bagi hasil), 50:50, atau 60:40 dan seterusnya setelah disepakati oleh pengurus koperasi dan anggota termasuk kaitannya dengan kemungkinan timbulnya risiko kerugian. Warga yang menerima pembiayaan dengan akad tersebut biasanya telah diarahkan usahanya setelah melalui berbagai pelatihan dan keikutsetaan dalam penyuluhan yang diselenggarakan pengurus baik di bidang pertanian seperti menanam buah dan sayur, atau di bidang peternakan seperti beternak ayam pedaging serta di bidang keterampilan seperti memproduksi kuliner dan kerajinan sebagai oleh-oleh khas desa.

4. Memberikan Pembiayaan dengan akad jual beli

Selain pembiayaan dengan akad mudharabah, Kopwan Syariah Mitra Surya Bahari juga memberikan pembiayaan kepada warga sebagai anggota dengan akad jual beli. Baik dengan skim jual beli murabaha, bai' salam maupun bai' bitsaman ajil, dengan ketentuan besaran nominal dan jangka waktu pembayaran jika pembayarannya melalui proses pengangsuran. Dan pada praktikya mayoritas warga menggunakan pembiayaan yang diberikan koperasi dengan akad bai' bitsaman ajil. Yakni koperasi menyediakan pembiayaan untuk membelikan barang yang diinginkan warga ke produsen secara tunai, lalu menjualnya kepada anggota yang membutuhkan dengan harga tertentu setelah disepakati antara keduanya dengan pembayaran diangsur tanpa mengenakan denda keterlambatan pembayaran. Penyicilan atau angsuran biasanya 
ditarik pada setiap kumpul arisan.

5. Mendistribusikan dana Zakat, Infaq dan Shadaqah

Kopwan Syariah juga membagikan zakat infaq dan shadaqah untuk para warga yang tidak mampu dan masuk sebagai kategori penerima zakat secara langsung maupun tidak langsung. Secara langsung dalam atian dana zakat, infaq ataupun shadaqah yang diperoleh dari muzakki (pengeluar dana zakat) diberikan langsung kepada parra anggota yang berhak, atau tidak langsung dengan caa diberikan dalam bentuk pembiayaan dengan akad tabarru' dan qardul hasan.

6. Memberikan Arahan dan Menjadi Fasilitator Pelatihan Kerja untuk Anggota Koperasi Wanita Syariah Mitra Surya Bahari tidak hanya memberikan pembiayaan modal usaha, akan tetapi mengupayakan juga bagaimana pemberdayaan anggotanya terutama bagi mereka yang belum berdaya. Para anggota koperasi didorong untuk produktif dengan diberikan pelatihan dalam berbagai keahlian, mulai dari menjahit, desainer, tata rias, hingga produksi dan berjualan kuliner.

7. Pengayoman Anggota oleh Ketua dan sesama Anggota.

Kopwan Syariah Mitra Surya Bahari tidak hanya menjadi lembaga penyedia pembiayaan dan simpanan para anggota, akan tetapi lebih dari itu Kopwan Syariah Mitra Surya Bahari sebagai rumah keluarga besar yang saling memberikan pengayoman antar anggota satu dengan yang lainnya, serta menjadi rumah yang salang membantu dan saling support untuk kesejahteraan dan kebaikan bersama.

\section{KESIMPULAN}

Secara umum langsung ataupun tidak langsung keberadaan Kopwan syariah Mitra Surya Bahari bagi masyarakat desa Aeng Dake kecamatan Bluto Kabupaten Sumenep sangat besar perannya dalam membantu perekonomian mereka, terutama dalam memenuhi kebutuhan modal untuk meningkatkan usaha mereka. Dominasi orientasi berdirinya yang sejatinya memang untuk menolong dan membantu warga dan tidak semata-mata untuk tujuan komersil sangat dirasakan manfaatnya oleh warga dan turut serta membantu warga keluar dari jeratan hutang serta meminimalisir hubungan mereka dengan rrentenir atau lembaga keuangan ribawi.

\section{DAFTAR PUSTAKA}

Afrianti, (2010). Strategi Koperasi Jasa Keuangan Syariah dalam Menkan Tinggi Non Performing Financing (Studi Kasus Pada KJK Syariah Arrahman Ciere) Jakarta : UIN Syarif Hidayatullah.

Antonio, Muhammad Syafi'i, (2009). Bank Syari'ah dari Teori ke Praktik, Jakarta: Gema Insani Pres.

Arikunto, Suharsimi (2002). Prosedur Penelitian Suatu Pendekatan Praktek, Jakarta : Rineka Cipta.

Bakar M.D., dan Ali E.R.A.A. (2008), Essential Readings In Islamic Finance, Malaysia: CERT Publication. 


\section{Vol. 2 No. 1 June 2020}

Bungin, Burhan, (2008). Analisis Data Penelitian Kualitatif : Pemahaman Filosofis dan Metodologis ke Arah Penguasaan Model Aplikasi, Jakarta : Raja Grafindo.

Depateme Pendidikan Nasional, (2003). Kamus Besar Bahasa Idonesia, Jakarta: Balai Pustaka.

El-Diwany, Tarek (2003). The Problem with Interest (Sistem Bunga dan Permasalahannya, Terj) alih bahasa Amdiar Amir, Jakarta: Akbar Mediar Eka Sarana.

Islahi, Abdul Azim (1998) Economic Concepts of Ibn Taimiya London UK : The Islamic Foundation.

Janwari, Yadi, (2000). Lembaga-lembaga Perekonomian Syariah, Bandung: Pustaka Mulia dan Fakultas Syariah IAIN SGD.

Karim, Adiwarman A. (2009). Bank Islam Analisis Fiqih Dan Keuangan, Jakarta: PT. RajaGrafindo Prsada.

Moleong, Lexy J. (1998). Metodologi Penelitian Kualitatif, Bandung: PT. Remaja Rosdakarya.

Muhammad, (2002). Manajemen Bank Sariah, Yogyakarta: UPP AMP YKPN

Nazir, Habib, dkk (2008) Ensikopledi Ekoomi \& Pebankan Syariah, Bandung: kafa publishing.

Nur S Buchori dalam Afrianti, (2010). Strategi Koperasi Jasa Keuangan Syariah dalam Menekan Tinggi Non Performing Financing (Studi Kasus Pada KJK Syariah Arrahman Ciere) Jakarta : UIN Syarif Hidayatullah.

Ritongga,dkk. (2003). Pelajaran Ekonomi, Jakarta : PT. Gelora Aksara 